\title{
EFFECTS OF HEXAMETHYLPHOSPHORAMIDE ON RAT SPERMATOGENESIS AND FERTILITY
}

\author{
H. JAGKSON, A. R. JONES AND E. R. A. COOPER \\ Unit of Reproductive Pharmacology, University of Manchester, Manchester 13 \\ (Received 12th September 1968, revised 12th May 1969)
}

Summary. Hexamethylphosphoramide, an important industrial solvent, has been investigated because of its damage potential to reproductive cells. Male rats of proven fertility were given consecutive daily doses at prescribed levels and fertility data were obtained by serial mating. Aspermia in rats followed oral treatment with twenty-one doses of $100 \mathrm{mg} / \mathrm{kg}$ and five doses of $500 \mathrm{mg} / \mathrm{kg}$. The former dose induced sterility between the 6th and 12 th weeks and fertility did not return in a majority of animals. The histological results at both dose levels were consistent with an antispermatogenic action and correlated with the effects observed on fertility. In the pituitary glands of the sterilized males, considerable enlargement of basophil cells occurred. Simple modifications in the chemical structure of HMPA resulted in loss of the sterilizing action.

\section{INTRODUCTION}

Hexamethylphosphoramide(hexamethylphosphoric triamide,Hempa,HMPA, I)

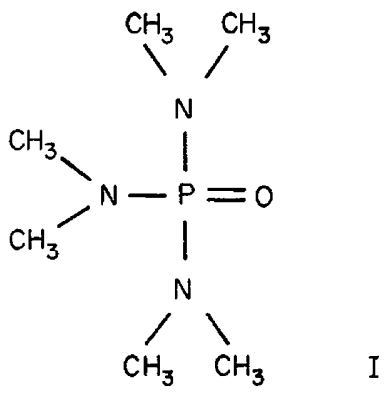

is a compound with widespread uses in industry so that an appraisal of its damage potential to reproductive cells is an important matter, apart from any possible application in the field of chemosterilization. By Normant (1967), it is considered as 'the most remarkable aprotic solvent' and described as a very versatile compound on account of its powerful solvent properties, especially for gases and a wide range of polymers. HMPA is incorporated into polyolefins as a stabilizer against deterioration from exposure to ultra-violet light; in plastics, it 
is used to impart antistatic properties and also added to motor fuels for the removal of deposits from internal combustion engines. Suggested applications in the biological sphere include incorporation into systemic insecticides, while addition-compounds formed with many organic chemicals are considered to have potential as antiseptics and germicides.

This paper presents a further contribution to the limited information available on the effects of HMPA upon male reproductive cells and fertility in experimental rodents (Kimbrough \& Gaines, 1966; Jackson \& Craig, 1966, 1969).

\section{MATERIALS AND METHODS}

Hexamethylphosphoramide was obtained from various sources and its effect on fertility compared with that of material purified by preparative gas-liquid chromatography. Other compounds used in this work were prepared by methods described or referred to elsewhere (Jones \& Jackson, 1968).

The rats used were of a Wistar strain originally obtained from the United States which have maintained a high reproductive rate over many years. They were fed on standard pellet diet with no supplements.

Fertility data were obtained by a serial mating procedure applied to treated males of proven fertility (Bock \& Jackson, 1957; Jackson, Fox \& Craig, 1961).

For histological examination, the testes and epididymides were fixed in Bouin's solution for $24 \mathrm{hr}$ then cut transversely across the equator and transferred to $70 \%$ alcohol for processing in the usual way. Sections were cut at $6 \mu$ and stained with haematoxylin. Pituitary glands were fixed in $7 \%$ formol-saline, processed, and sections stained with Mallory's phosphomolybdic stain.

\section{RESULTS}

Six consecutive doses of HMPA ( $500 \mathrm{mg} / \mathrm{kg}$ by mouth) were just tolerable in the American Wistar strain of rat. This course of treatment rapidly induced sterility in male rats due to aspermia and, as in the rabbit (Jackson \& Craig, 1966), this was not accompanied by loss of mating activity. Material obtained from two commercial sources gave essentially the same anti-fertility pattern as that purified by preparative gas chromatography (Table 1). The sterilizing ability rapidly declined with dose (Table 1) but the compound was mildly cumulative and striking effects were produced by 3 weeks of daily oral treatment $(100 \mathrm{mg} / \mathrm{kg}$; Table 2). Although continuing to gain weight, all animals became sterile in the 6th week and remained so for almost 3 months (Table 2); in fact only three of eight males recovered their fertility after 6 months (Table 3 ). One half of this dose rate did not produce consistent phases of sterility in the treated males and $25 \mathrm{mg} / \mathrm{kg}$ by mouth daily for 1 month had no effect on fertility (Table 2).

The histological results are consistent with an antispermatogenic action and correlate with the effects observed on fertility. Gonads from the $50 \mathrm{mg} / \mathrm{kg}$ treatment group provided no significant evidence of damage to the seminiferous epithelium whereas animals receiving $100 \mathrm{mg} / \mathrm{kg}$ showed severe damage to the testes by the end of treatment ( 3 weeks). Most of the tubules were depopulated 


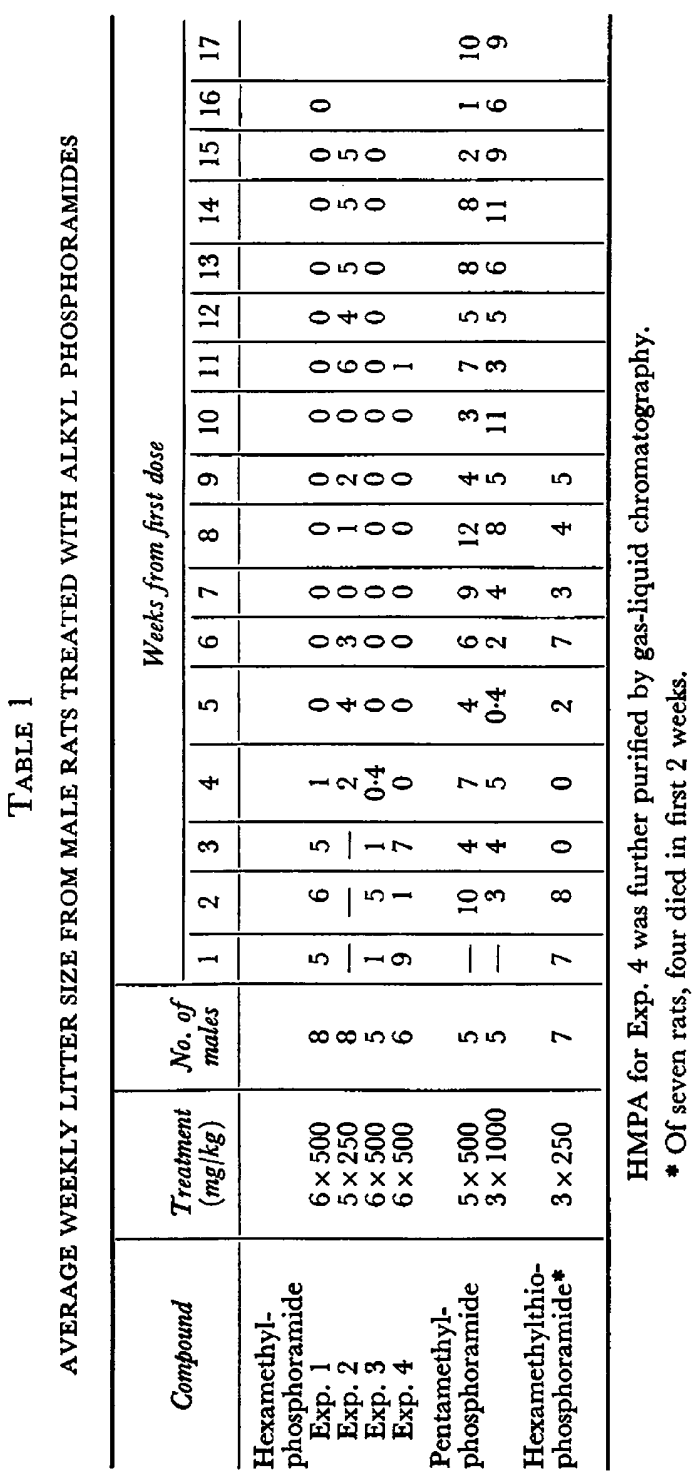




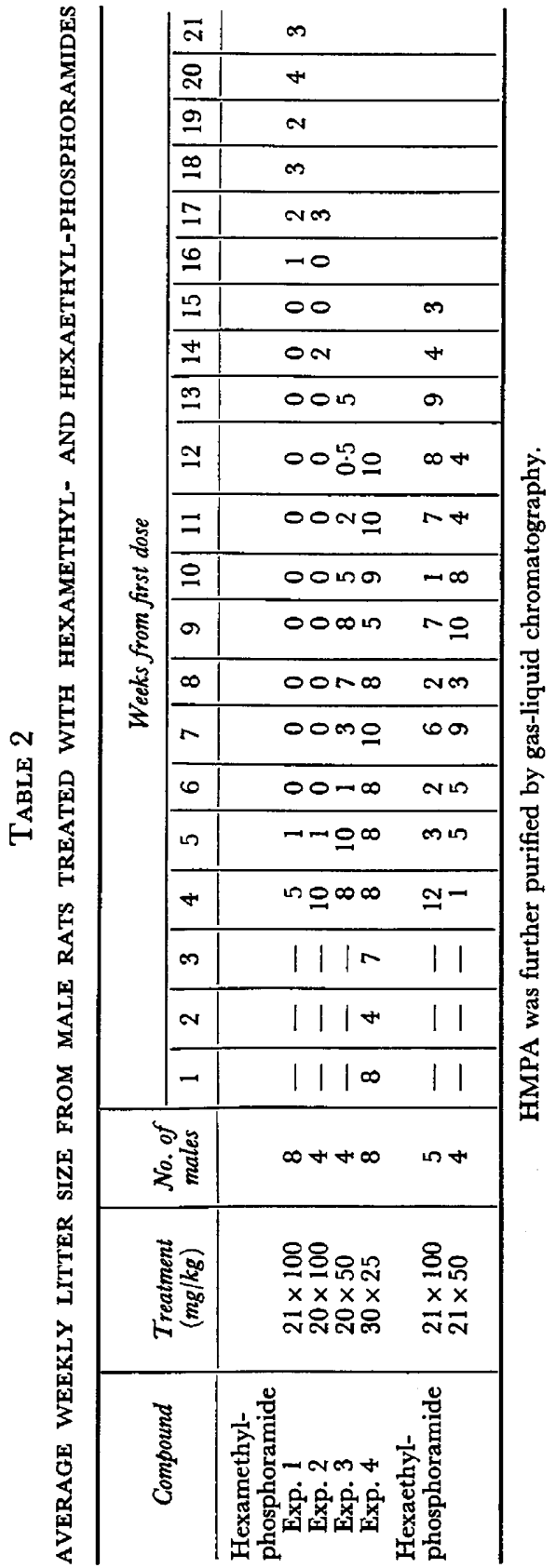




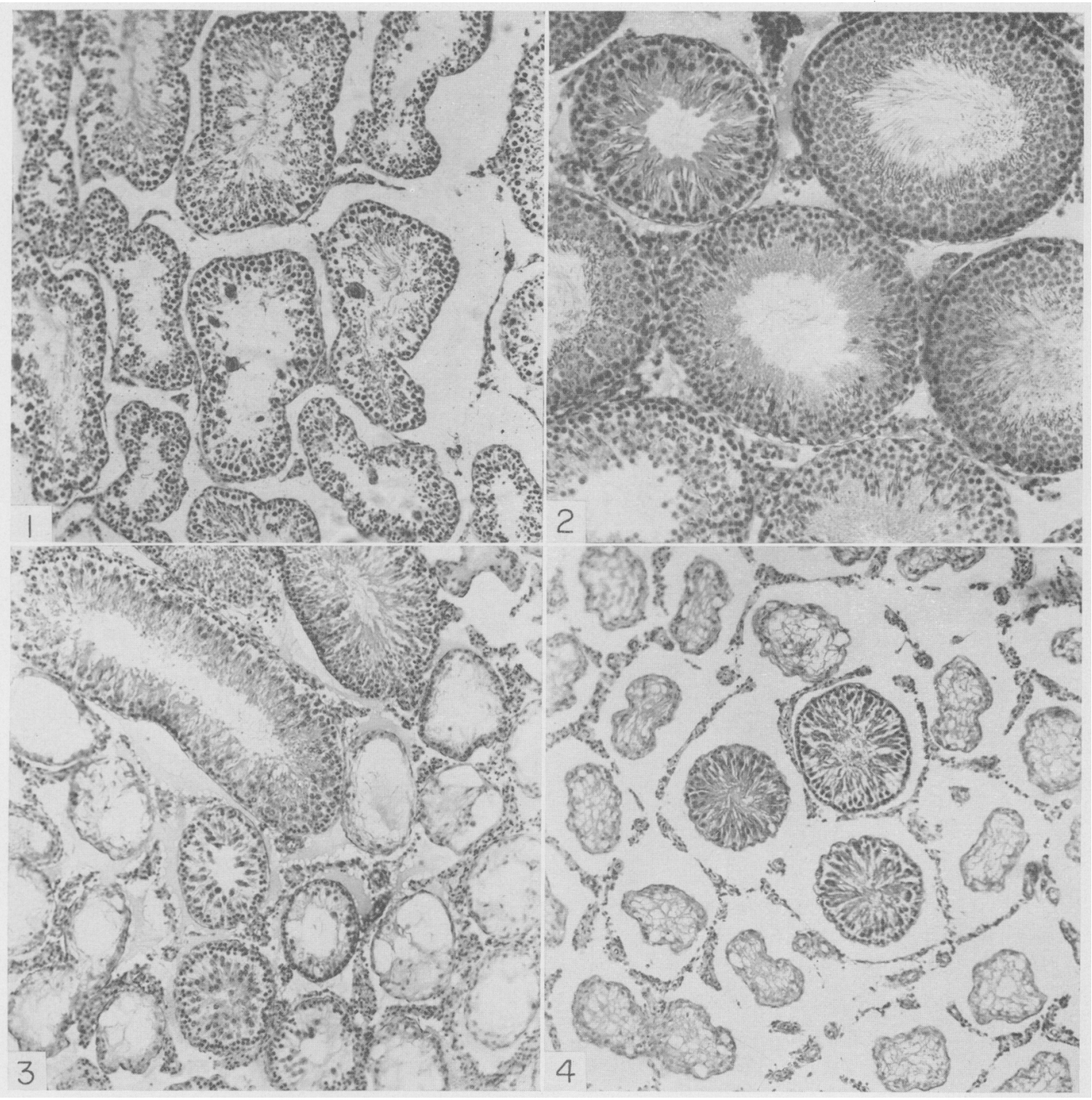

Fic. 1. Testis. $20 \times 100 \mathrm{mg} / \mathrm{kg} ; 3$ wreks after first dose; depopulation of tubules, giant colls visible in some. $\times 72$.

lig. 2. Testis. $20 \times 100 \mathrm{mg} / \mathrm{kg} ; 18$ weeks after first dose; completerecorcry in most tubules. $\times 72$.

Fis. 3. Testis. $20 \times 100 \mathrm{mg} / \mathrm{kg} ; 18$ weeks after first dose; complete recorery in some tubules, little or no recorery in others. $\times 72$.

Fig. 4. Testis. $5 \times 500 \mathrm{mg} / \mathrm{kg} ; 14$ weeks after first dose; majority of tubules contain only Sertoli cells, but a few show signs of repopulation. $\times 72$. 

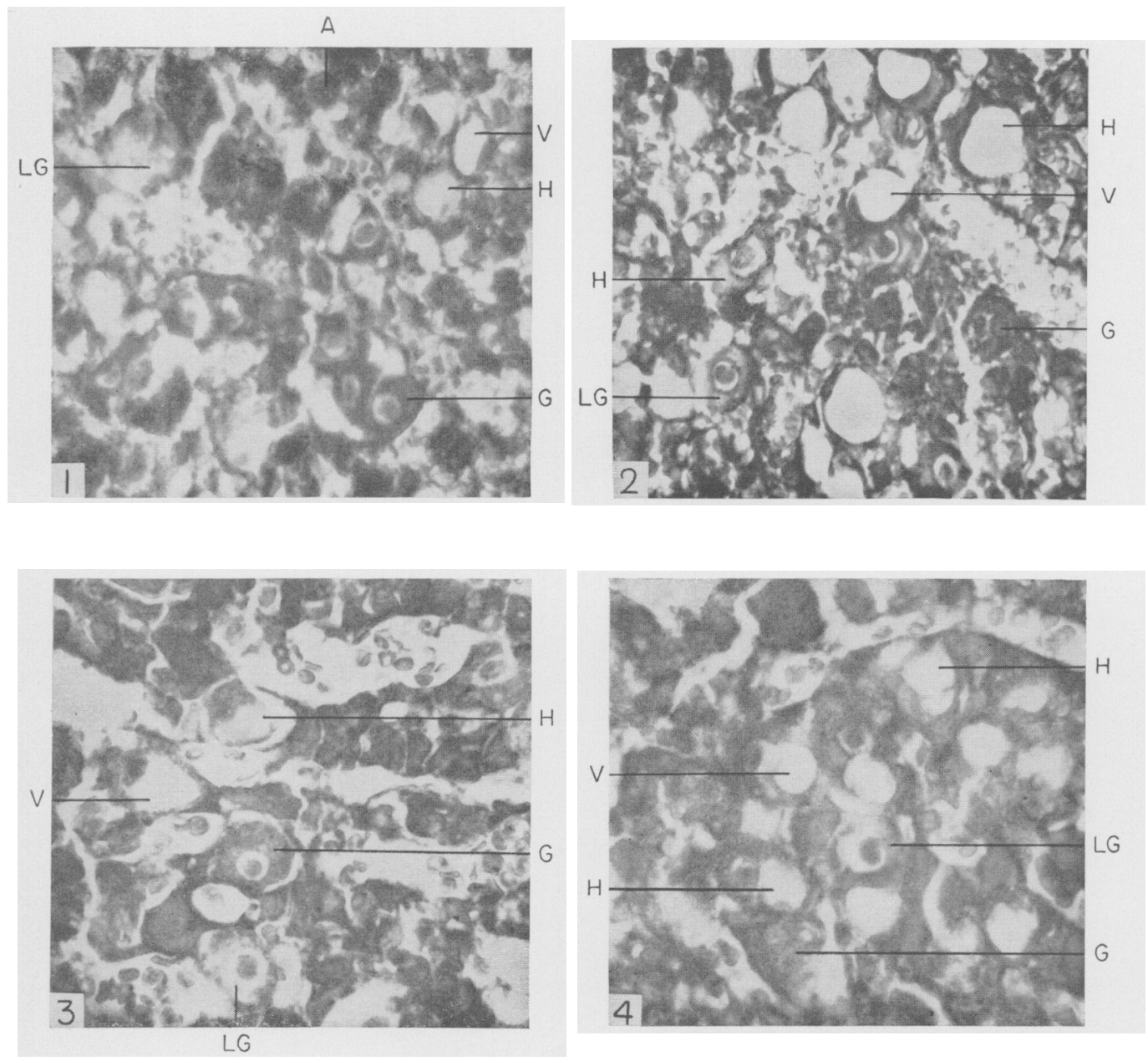

Pituitaries, $\times 45 \%$. Basephil cells in pars anterior of the pituitary are indicated as follows: G-granular; I.C $x$ - losing granules; H-hyalinized; V-vacuolated. $A \cdots$ acidophil cell (Mallory's acid fuchsin aniline blue orange $G$ stain).

Fici. 1. Control.

fro. $2.20 \times 100 \mathrm{mg} / \mathrm{kg} ; 18$ weeks after first dose.

Firsis. 3 and $4.5 \times 500 \mathrm{mg} / \mathrm{kg} ; 14$ weeks after first dose. 
and giant cells were frequent (Pl. 1, Fig. 1). However, rat testes examined 18 weeks after the first dose showed full spermatogenesis in some tubules (Pl. 1, Fig. 2) although others remained depopulated and contained only Sertoli cells (Pl. 1, Fig. 3). Dosage of $500 \mathrm{mg} / \mathrm{kg}$ daily for 5 or 6 days produced drastic changes in the testes of all animals. The tubules remained small after 14 weeks, the majority containing only Sertoli cells (Pl. 1, Fig. 4), although some showed evidence of spermatogenic activity. Interstitial tissue appeared normal.

TABLE 3

AVERAGE WEEKLY LITTER SIZE FOR EIGHT MALE RATS TREATED WITH HEXAMETHYLPHOSPHORAMIDE

\begin{tabular}{|c|c|c|c|c|c|c|c|c|c|c|c|c|c|c|c|c|c|c|c|c|}
\hline \multirow{2}{*}{ No. of males } & \multicolumn{20}{|c|}{ Weeks from first dose* } \\
\hline & 4 & 5 & 6 & 7 & 8 & 9 & 10 & 11 & 12 & 13 & 14 & 15 & 16 & 17 & 18 & 19 & 20 & 21 & 22 & 23 \\
\hline $\begin{array}{l}3 \\
5\end{array}$ & $\begin{array}{l}4 \\
5\end{array}$ & $\begin{array}{l}1 \\
1\end{array}$ & $\begin{array}{l}0 \\
0\end{array}$ & $\begin{array}{l}0 \\
0\end{array}$ & $\begin{array}{l}0 \\
0\end{array}$ & $\begin{array}{l}0 \\
0\end{array}$ & $\begin{array}{l}0 \\
0\end{array}$ & $\begin{array}{l}0 \\
0\end{array}$ & $\begin{array}{l}0 \\
0\end{array}$ & $\begin{array}{l}0 \\
0\end{array}$ & $\begin{array}{l}0 \\
0\end{array}$ & $\begin{array}{l}0 \\
0\end{array}$ & $\begin{array}{l}4 \\
0\end{array}$ & $\begin{array}{l}4 \\
0 \dagger\end{array}$ & $\begin{array}{l}6 \\
0\end{array}$ & $\begin{array}{l}6 \\
0\end{array}$ & $\begin{array}{l}9 \\
0\end{array}$ & $\begin{array}{l}9 \\
0\end{array}$ & $\begin{array}{l}7 \\
0\end{array}$ & $\begin{array}{l}6 \\
0\end{array}$ \\
\hline $\begin{array}{l}\text { No. 'aspermic' } \\
\text { No. fertile }\end{array}$ & $\begin{array}{l}2 \\
6\end{array}$ & $\begin{array}{l}4 \\
2\end{array}$ & $\overline{0}$ & $\begin{array}{l}7 \\
0\end{array}$ & $\begin{array}{l}7 \\
0\end{array}$ & $\begin{array}{l}6 \\
0\end{array}$ & $\begin{array}{l}8 \\
0\end{array}$ & $\begin{array}{l}8 \\
0\end{array}$ & $\begin{array}{l}8 \\
0\end{array}$ & $\begin{array}{l}6 \\
0\end{array}$ & $\begin{array}{l}7 \\
0\end{array}$ & $\begin{array}{l}8 \\
0\end{array}$ & $\begin{array}{l}5 \\
1\end{array}$ & $\begin{array}{l}4 \\
3\end{array}$ & $\begin{array}{l}1 \\
2\end{array}$ & $\begin{array}{l}4 \\
2\end{array}$ & $\begin{array}{l}4 \\
4\end{array}$ & $\begin{array}{l}4 \\
3\end{array}$ & $\begin{array}{l}3 \\
3\end{array}$ & $\begin{array}{l}4 \\
2\end{array}$ \\
\hline
\end{tabular}

* Twenty-one consecutive daily doses of $100 \mathrm{mg} / \mathrm{kg}$ by mouth in water.

$\dagger$ One male died.

The selective nature of the action of HMPA is evident from general autopsy data regarding organ weights and is consistent with a direct action upon the spermatogenic cells. The testis weight, 18 weeks after treatment with $100 \mathrm{mg} / \mathrm{kg}$, was reduced by $50 \%$, while the weights of accessory sexual organs, adrenals, thyroid and pituitary were in the normal range. No histological change was observed in the pituitaries of animals examined at the conclusion of treatment. However, in the $20 \times 100 \mathrm{mg} / \mathrm{kg}$ and $5 \times 500 \mathrm{mg} / \mathrm{kg}$ groups there was, after 18 weeks, enlargement of basophil cells associated with coarse granulation, loss of granules, hyalinization and vacuolation (Plate 2). It has long been known that destruction of the seminiferous epithelium by radiation is followed by enlargement in basophil cells (Mottram \& Cramer, 1923) and there is other evidence in favour of a feed-back mechanism from the seminiferous epithelium to the pituitary (Johnsen, 1964; Lacy, 1967). The changes described above might therefore be ascribed to a disturbance of pituitary function following the elimination of seminiferous cells by HMPA, leaving interstitial cell activity unaffected. Removal of the testes is known to induce basophilic 'castration' cell formation in the pituitary.

With these courses of treatment, no changes were observed in the white cell count, but Kimbrough \& Gaines (1966) reported, and we have confirmed, that oral treatment of rats with HMPA from two commercial sources for 6 weeks at $100 \mathrm{mg} / \mathrm{kg}$ produced multiple lung abscesses. Neither pentamethylphosphoramide (Table 1) nor hexaethylphosphoramide (Table 2) showed sterilizing activity in the rat. Hexamethylthiophosphoramide was more toxic than HMPA, and the survivors after three doses of $250 \mathrm{mg} / \mathrm{kg}$ showed sterility in Weeks 3 and 4 (Table 1 ). 


\section{DISGUSSION}

The antispermatogenic and antifertility activity of HMPA are obviously of interest from viewpoints of industrial hazards to man and possible use as a male chemosterilizing agent in the control of biological populations. In the present study, sterility was induced in rats by $100 \mathrm{mg} / \mathrm{kg}$ daily for 3 weeks; some effect was perceptible at $50 \mathrm{mg} / \mathrm{kg}$ daily but $25 \mathrm{mg} / \mathrm{kg}$ daily for 1 month produced no effect on weekly litter size. Whilst this seems reassuring from the hazard point of view, it is important to bear in mind that fertility is a crude assessment of testicular function as even a small amount of spermatogenic tissue can maintain a normal level of fertility. More prolonged courses of treatment would be required to provide a thoroughly convincing answer to the question of cumulative damage to reproductive cells.

The discovery of the action of HMPA in the housefly (Chang, Terry \& Borkovec, 1964) and the seeming resemblance between its structure and that of triethylenephosphoramide (TEPA, II) led to studies of structure/activity

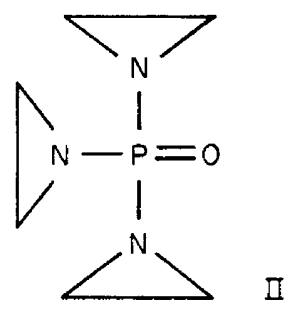

relationships with the synthesis of compounds intermediate between HMPA and TEPA. Interchange of the alkylamino groups led to an inhibition of the biological activity against the housefly whilst the effects of mixtures of HMPA and TEPA were only additive (Chang \& Borkovec, 1966).

The antifertility effects of HMPA and TEPA correlate in male insect and male rodent so far as relative potency is concerned. However, the action on spermatogenic cells of the two chemical types is very different in rodents. HMPA operates essentially by producing aspermia following destructive effects on spermatids and spermatocytes and the action can extend to spermatogonia, resulting in protracted sterility. Basically, TEPA causes the production of morphologically intact, motile spermatozoa which are functionally incompetent, as do certain other aziridines like tretamine (TEM) (Jackson et al., 1961).

The need for relatively high dosage of HMPA to produce chemosterilization of houseflies (Chang et al., 1964) or sterility in rats, raised the possibility that the action could be due to some metabolite. In fact, pentamethylphosphoramide, the major metabolite in the rat (Jones \& Jackson, 1968) and sole metabolite in the housefly (Chang, Terry, Woods \& Borkovec, 1967), did not produce sterility in the rat.

Hexamethylthiophosphoramide (thioHMPA) showed sterilizing activity but proved to be considerably more toxic than HMPA to the rat, results which paralleled those obtained in the housefly (Terry \& Borkovec, 1965). Finally, hexaethylphosphoramide was found to be ineffective following 3 weeks of 
daily treatment (Table 2). Thus the presence of six methyl groups in the phosphoramide molecule is essential for the antifertility action. It is possible that one of these groups is operative in the antispermatogenic mechanism (e.g. by alkylation) although the functional type of sterility produced by the methyl donors, methylmethanesulphonate (Jackson et al., 1961) and trimethylphosphate (Jackson \& Jones, 1968), render this less likely.

The interesting antifertility activity of the HMPA molecule is seen to be highly specific and provides little scope for systematic structural modifications. At present, it is not possible to predict structure/activity relationships but the specific actions of known compounds implies that a more intensive search will lead to further discoveries in this field.

\section{ACKNOWLEDGMENTS}

This work was supported by grants from the Ford Foundation and the Wellcome Trust. We are grateful to Mrs E. R. Carlin for technical assistance.

HMPA for Exps. 1 and 2 was synthesized by Dr A. B. Borkovec, U.S.D.A., Chemosterilant Division, Beltsville, Maryland. That used in Exp. 3 was obtained from the Industrial Toxicological Laboratories of Eastman Kodak Ltd, Rochester, New York, by courtesy of Dr D. W. Fassett.

\section{REFERENCES}

Bock, M. \& JAckson, H. (1957) The action of triethylenemelamine on the fertility of male rats. Br. $\mathcal{F}$. Pharmac. Chemother. 12, 1 .

Chang, S. C. \& Borkovec, A. B. (1966) Structure activity relationships in analogues of TEPA and HMPA. F. econ. Ent. 59, 1359.

Chang, S. C., Terry, P. H. \& Borkovec, A. B. (1964) Insect chemosterilants with a low toxicity for mammals. Science, N.Y. 144, 57.

Chang, S. C., Terry, P. H., Woods, C. W. \& Borkovec, A. B. (1967) Metabolism of HMPA uniformly labelled with ${ }^{14} \mathrm{C}$ in male house flies. F. econ. Ent. 60, 1623.

Jackson, H. \& Craig, A. W. (1966) Antifertility action and metabolism of hexamethylphosphoramide. Nature, Lond. 212, 86.

JACKson, H. \& CRAIG, A. W. (1969) Effects of alkylating chemicals on reproductive cells. Ann. N.Y. Acad. Sci. (in press).

Jackson, H., Fox, B. W. \& Craig, A. W. (1961) Antifertility substances and their assessment in the male rodent. 7. Reprod. Fert, 2, 447.

JACKson, H. \& JoNEs, A. R. (1968) Antifertility action and metabolism of trimethylphosphate in rodents. Nature, Lond. 220, 591.

Johnsen, S. G. (1964) Studies on the testicular-hypophyseal feed-back mechanism in man. Acta endocr., Copenh. Suppl. 90, 99.

Jones, A. R. \& Jackson, H. (1968) The metabolism of hexamethylphosphoramide and related compounds. Biochem. Pharmac. 17, 2247.

Kimbrough, R. \& Gaines, T. B. (1966) Toxicity of hexamethylphosphoramide in rats. Nature, Lond. $211,146$.

LACY, D. (1967) The seminiferous tubule in mammals. Endeavour, 26, 101.

Mottram, J. G. \& Cramer, W. (1923) On general effects of exposure to radium on metabolism and tumour growth in rat and special effects on testes and pituitary. Q. $\mathcal{F l}$ exp. Physiol. 13, 209.

Normant, H. (1967) Hexamethylphosphoramide. Angew. Chem. (Int. edn in English) 6, 1046.

Terry, P. H. \& Borkovec, A. B. (1965) Phosphoramides and thiophosphoramides as insect chemosterilants. U.S. Patent 3,205,130 Sept. 7. 